\title{
PERLINDUNGan HuKUM TERHADAP PEKERJA ANAK DI SEKTOR INFORMAL
}

\author{
M. Imam Tarmudzi \\ imamsinaga46@gmail.com \\ Dsn. Pandantoyo RT 06 RW 02 Ds. \\ Dukoh Kec.Temayang Kab. Bojonegoro
}

\begin{abstract}
This paper explains that Islamic criminal law had already set and explained the legal protection for child. Even, Islam itself protects child from anything that may harm him. The protections include: the childcare, supervision, protection and education. While in Law No. 23 Year 2002 on protection of child explains mechanism of a labor child protection which includes juridical protection, non judicial protection, and protection from slavery and exploitation of child. These laws equally prohibit child to work if it is not in accordance with the existing law. The difference is that law distinguishes between crime and violation based on the heavy and light of the punishment, while Islamic criminal law does not distinguish both. They all are called jarîmah (crime) by their nature of the crime.
\end{abstract}

Keywords: Legal protection, child labor, informal sector, Islamic criminal law.

Abstrak: Tulisan ini menjelaskan bahwa hukum pidana Islam sudah mengatur dan menjelaskan tentang perlindungan hukum bagi anak.I Islam mengatur tentang perlindungan terhadap anak dari sesuatu yang dapat membahayakan dirinya, yang meliputi; pengasuhan, pengawasan, perlindungan dan pendidikan. Dalam Undang-undang Nomor 23 Tahun 2002 tentang Perlindungan Anak menjelaskan tentang mekanisme perlindungan terhadap anak yang menjadi pekerja anak yang meliputi; perlindungan dalam bidang yuridis dan non yuridis, selain itu pula ada perlindungan dari perbudakan dan eksploitasi anak. Kedua hukum tersebut, hukum Islam dan Undang-undang Nomor 23 Tahun 2002 tentang Perlindungan Anak, sama-sama melarang anak bekerja jika tidak sesuai dengan syarat-syarat hukum yang berlaku, adapun perbedaannya adalah dalam Undang-undang membedakan antara kejahatan atau pelanggaran mengingat berat ringannya hukuman, sedangkan hukum pidana Islam tidak membedakannya, semuanya disebut jarîmah mengingat sifat pidananya.

Kata Kunci: Perlindungan hukum, pekerja anak, sektor informal. 


\section{Pendahuluan}

Pembicaraan tentang anak dan perlindungannya tidak akan pernah berhenti sepanjang sejarah kehidupan, karena anak adalah generasi penerus bangsa dan penerus pembangunan yaitu generasi yang dipersiapkan sebagai subjek pelaksana pembangunan yang berkelanjutan dan pemegang kendali masa depan suatu negara. Perlindungan anak berarti melindungi potensi sumber daya insani dan membangun manusia seutuhnya menuju masyarakat yang adil dan makmur. ${ }^{1}$

Anak merupakan bentuk investasi yang menjadi indikator keberhasilan suatu bangsa dalam melaksanakan pembangunan di masa depan. Keberhasilan pembangunan anak akan menentukan kualitas sumber daya manusia di masa yang akan datang, serta merupakan generasi yang akan menjadi penerus bangsa sehingga mereka harus dipersiapkan dan diarahkan sejak dini agar dapat tumbuh dan berkembang menjadi anak yang sehat jasmani dan rohani, maju, mandiri dan sejahtera, menjadi sumber daya yang berkualitas dan dapat menghadapi tantangan di masa datang. Oleh karena itu upaya pembangunan anak harus dimulai sedini mungkin mulai dari kandungan hingga tahap-tahap tumbuh kembang selanjutnya. ${ }^{2}$

Anak sebagai golongan rentan memerlukan perlindungan terhadap hak-haknya. Sebagaimana diketahui manusia adalah pendukung hak sejak lahir, dijelaskan Undang-Undang Republik Indonesia No. 23 Tahun 2002 tentang Perlindungan Anak, Pasal 1 Ayat 2 :

"Perlindungan anak adalah segala kegiatan untuk menjamin dan melindungi anak dan hak-haknya agar dapat hidup, tumbuh, berkembang dan berpartisipasi secara optimal sesuai dengan harkat dan martabat kemanusiaan, serta mendapat perlindungan dari kekerasan dan diskriminasi."

Pada hakekatnya, anak tidak boleh bekerja karena waktu mereka selayaknya dimanfaatkan untuk belajar, bermain, bergembira, berada dalam suasana damai, mendapatkan kesempatan dan fasilitas untuk mencapai cita-citanya sesuai dengan perkembangan fisik, psikologi, intelektual dan sosialnya. Namun pada kenyataannya banyak anak-anak

\footnotetext{
${ }^{1}$ Nashriana, Perlindungan Hukum Pidana bagi Anak di Indonesia (Jakarta: Raja Grafindo Persada, 2011), 1.

2 Lenny N. Rosalin, "Kabupaten/Kota Layak Anak untuk Mewujudkan Indonesia Layak Anak", http://www.kotalayak anak.org, (23 November 2013)

${ }^{3}$ Undang-Undang Republik Indonesia No. 23 Tahun 2002 tentang Perlindungan Anak, Pasal 1 Ayat 2.
} 
di bawah usia 18 tahun yang telah terlibat aktif dalam kegiatan ekonomi dan menjadi pekerja anak, antara lain di sektor informal dengan alasan tekanan ekonomi yang dialami orang tuanya ataupun faktor lainnya. ${ }^{4}$

Salah satu masalah anak yang harus memperoleh perhatian khusus, adalah isu pekerja anak (child labor). Isu ini telah mengglobal, karena begitu banyak anak-anak di seluruh dunia yang masuk bekerja pada usia sekolah. Pada kenyataannya, isu pekerja anak bukan sekedar isu anak menjalankan pekerjaan dengan memperoleh upah, akan tetapi lekat sekali dengan eksploitasi, pekerjaan berbahaya, terhambatnya akses pendidikan dan menghambat perkembangan fisik, psikis dan sosial anak. Bahkan dalam kasus dan bentuk tertentu pekerja anak telah masuk sebagai kualifikasi anak-anak yang bekerja pada situasi yang paling tidak bisa ditolerir. ${ }^{5}$

Banyak dari anak-anak ini yang berisiko terperangkap dalam bentuk-bentuk terburuk pekerja anak. Penghapusan pekerja anak didasarkan pada prinsip bahwa anak sepatutnya berada di sekolah, bukan di tempat kerja. Akan tetapi, statistik menunjukkan, organisasi buruh sedunia atau lebih deikenal dengan ILO menunjukkan data terbaru pada Juni 2013 bahwa di dunia terdapat 10,5 juta anak pekerja domestik yang potensial menjurus kepada kondisi perbudakan. Di Indonesia, Komisi Nasional Perlindungan Anak melansir data kasus terkait anak-anak selama semester pertama 2013. Jumlah pekerja anak di sektor informal mencapai 4,7 juta jiwa. ${ }^{6}$ Pemerintah Indonesia dengan Keputusan Presiden Nomor 36 tahun 1990, memuat empat prinsip umum tentang hak anak, yaitu:

1. Bahwa anak-anak dibekali dengan hak-hak tanpa kecuali;

2. Bahwa anak-anak mempunyai hak untuk hidup dan berkembang;

3. Bahwa kepentingan anak harus menjadi pertimbangan utama dalam semua keputusan atau tindakan yang mempengaruhi anak;

4. Bahwa anak-anak diperbolehkan untuk berpartisipasi sebagai peserta aktif dalam segala hal yang mempengaruhi hidupnya. ${ }^{7}$

\footnotetext{
${ }^{4}$ Syamsuddin, Petunjuk Pelaksanaan Penanganan Anak yang Bekerja (Jakarta: Departemen Tenaga Kerja Republik Indonesia 1997), 1.

${ }^{5}$ Muhammad Joni Zulechaina, Tanamas, Aspek Hukum Perlindungan Anak dan Perspektif Konvensi Hak-hak Anak (Bandung: Citra Aditya Bakti, 1999), 8.

6 Sovalusian, "Analisis Studi Kasus Pekerja Anak" dalam http://sovalusian.blogspot.com, (19 Oktober 2013).

7 Eka Cahyanto, Pedoman Teknis Pelayanan Pendidikan bagi Pekerja Anak Sektor Informal (Jakarta: Depdiknas, 2001), 24.
} 
Berdasarkan Undang-undang tentang perlindungan anak yaitu UU No. 23 Tahun 2002 dengan tujuan perlindungan terhadap anak memiliki dasar hukum yang kuat. Di dalam UU No. 23 Tahun 2002 dijelaskan definisi perlindungan anak di dalam Bab I Ketentuan Umum Pasal 1 (2) yang berbunyi: "Perlindungan anak adalah segala kegiatan untuk menjamin dan melindungai anak dan hak-haknya agar dapat hidup, tumbuh, berkembang, dan berpartisipasi secara optimal sesuai dengan harkat dan martabat kemanusiaan, serta mendapat perlindungan dari kekerasan dan diskriminasi". ${ }^{8}$

Anak dalam keadaan tertentu itu akan mendapatkan perlindungan khusus. Mengenai definisi perlindungan khusus itu sendiri dalam UU No. 23 Tahun 2002 diatur pada pasal 1 ayat 15 yang berbunyi :

"Perlindungan khusus adalah perlindungan yang diberikan kepada anak dalam situasi darurat, anak yang berhadapan dengan hukum, anak dari kelompok minoritas dan terisolasi, anak yang dieksploitasi secara ekonomi dan/atau seksual, anak yang diperdagangkan, anak yang menjadi korban penyalahgunaan narkotika, alkohol, psikotropika, dan zat adiktif lainya (napza), anak yang menyandang cacat, dan anak korban perlakuan salah dan penelantaran".?

Undang-Undang Republik Indonesia No.13 Tahun 2003 tentang Tenaga Kerja disebutkan pngertian anak yaitu: "Anak adalah setiap orang yang berumur di bawah 18 (delapan belas) tahun". Dalam keadaan apapun dan dengan alasan apapun pengusaha tidak boleh mempekerjakan anak di bawah umur. Namun dalam upaya untuk memberikan pendidikan dan pelatihan, pengusaha boleh mempekerjakan anak-anak dengan ketentuan yang berlaku sebagaimana dijelaskan dalam Undang Undang Republik Indonesia No.13 Tahun 2003 tentang Tenaga Kerja dari pasal $68,69,70,71,72,73,74,75 .^{10}$

Pekerjaan di sektor informal sangat berpotensi mengancam keselamatan, kesehatan, kebebasan anak dalam bermain, belajar dan terancam dari tindakan eksploitasi terhadap anak. Oleh karena itu pekerjaan tersebut tidak diperbolehkan dikerjakan oleh anak-anak. Tindakan mempekerjakan anak dalam pekerjaan terburuk bagi anak

\footnotetext{
${ }^{8}$ Undang-Undang Republik Indonesia No. 23 Tahun 2002 tentang Perlindungan Anak, Pasal 1 Ayat 15.

${ }^{9}$ lbid.

${ }^{10}$ Undang-Undang Republik Indonesia No. 13 tahun 2003 tentang Tenaga Kerja, Pasal 1 Ayat 2.
} 
dikategorikan sebagai kejahatan, oleh karena itu setiap pelanggar ketentuan tersebut akan dikenai sanksi pidana. Negara berkembang dan fenomena pekerja anak di sektor informal seolah tidak dapat lepas. Pekerja anak di sektor informal sering dianggap sebagai respon tehadap kemiskinan di negara berkembang karena pekerja anak di sektor informal merupakan sebagian besar dari golongan penduduk miskin Indonesia. Di sektor informal, peran negara sebagai pelindung kelompok masyarakat miskin menjadi minim jika tidak dapat dikatakan hilang. Di sektor informal tingkat pendapatan pekerja rendah, tidak ada kepastian pekerjaan serta lemahnya jaminan sosial. ${ }^{11}$

Dalam Islam, perintah untuk menjaga sekaligus melindungi anak merupakan suatu keharusan sebagaimana firman Allah:

"Hai orang-orang yang beriman, peliharalah dirimu dan keluargamu dari api neraka yang bahan bakarnya adalah manusia dan batu; penjaganya malaikat-malaikat yang kasar, yang keras, yang tidak mendurhakai Allah terhadap apa yang diperintahkanNya kepada mereka dan selalu mengerjakan apa yang diperintahkan. ${ }^{12}$ (QS. At-Tahrim ayat 6)

Penjabaran tentang pemeliharaan dalam surat At-Tahrim ayat $6 \mathrm{di}$ atas cukup jelas jangkauannya. Pemeliharaan dan pengurusan anak merupakan perwujudan nyata dan tanggung jawab terhadap anak. Peningkatan kesadaran terhadap anak merupakan kunci keberhasilan dalam permasalahan mengasuh anak yang dipersiapkan menjadi anggota masyarakat yang bermanfaat dan menjadi warga negara yang baik.

Nabi Muhammad saw mewajibkan para majikan untuk memberikan gaji pegawainya tepat waktu, tanpa dikurangi sedikit pun. Dari Abdullah bin Umar ra, Nabi saw bersabda dalam HR. Ibn Majah dan dishahihkan al-Albani:

"Berikanlah upah pegawai (buruh), sebelum kering keringatnya."

Islam memberi peringatan keras kepada para majikan yang menzalimi pembantunya atau pegawainya. Dalam hadis qudsi dari Abu Hurairah ra, Nabi saw meriwayatkan, dalam HR. Ibn Majah dan dishahihkan al-Albani :

\footnotetext{
${ }^{11}$ Ari Hernawan, "Perlindungan Hukum bagi pekerja Sektor Informal di Negara Berkembang", http://www.pkbh.ugm.ac.id/artkl.html, (18 November 2013).

${ }^{12}$ Departemen Agama RI, Al-Qur'an Tajwid dan Terjemahnya (Bandung: Diponegoro, 2008), 951.
} 
"Ada tiga orang, yang akan menjadi musuh-Ku pada hari kiamat: orang yang mempekerjakan seorang buruh, si buruh memenuhi tugasnya, namun dia tidak memberikan upahnya (yang sesuai)." 13

Maka dari itu anak tidak boleh dipekerjakan karena belum dewasa, fase seorang anak menginjak dewasa. Menurut jumhur ahli hukum Islam, kedewasaan itu pada pokoknya ditandai dengan tandatanda fisik berupa ihtilâm atau haid, namun bilamana tanda-tanda itu tidak muncul pada saatnya, maka kedewasaan ditandai dengan umur yaitu 15 tahun. Ahli-ahli hukum Hanafi menyatakan dewasa itu adalah usia 18 tahun bagi orang laki-laki dan 17 tahun bagi perempuan. ${ }^{14}$

Berdasarkan hal di atas, maka makalah ini membahas tentang perlindungan hukum bagi anak yang bekerja di sektor informal perspektif undang-undang dan fiqh.

\section{Pengertian Anak dalam Hukum Islam}

Anak menurut bahasa adalah keturunan kedua sebagai hasil antara hubungan pria dan wanita. Adapun ada istilah anak Adam itu mempunyai arti umum bagi seluruh manusia, karena Adamlah manusia pertama yang diciptakan Allah. ${ }^{15}$ Dalam bahasa Arab, terdapat dua kata yang berarti anak, yaitu:

a. Walad, mempunyai arti anak secara umum. Baik anak yang dilahirkan oleh manusia, maupun binatang yang dilahirkan oleh induknya. ${ }^{16}$

b. Ibn, yang berarti anak manusia. ${ }^{17}$

Penggunaan kedua kata (walad dan ibn) dalam penerapannya berbeda. Walad dipakai untuk istilah anak secara umum, baik anak manusia atau anak binatang. Sedangkan kata ibn hanya dipakai untuk manusia. $^{18}$

Pengertian anak muncul karena adanya bapak dan ibu, anak merupakan hasil perbuatan persetubuhan antara seorang laki-laki dengan seorang perempuan, maka lahirlah dari tubuh perempuan tersebut

\footnotetext{
13 Ibid., 865.

${ }^{14}$ Rofiq Nasihudin, "Pekerja Anak Bawah Umur Menurut Hukum Islam", http://www.nasihudin.com, (18 November 2013).

${ }^{15}$ Fuad Mochamad Fachruddin, Masalah Anak dalam Hukum Islam Anak Kandung, Anak Tiri dan Anak Zina (Jakarta: Pedoman Jaya, 1985), 38.

${ }^{16}$ Attabik Ali \& A. Zuhdi Muhdlor, Kamus Kontemporer Arab Indonesia (Jogjakarta: Multi Karya Grafika, 2003), 3029.

17 Ibid., 12.

${ }^{18}$ Fuad Mochamad Fachruddin, Masalah Anak dalam Hukum Islam, 40.
} 
seorang manusia yang nantinya akan mengatakan seorang laki-laki tadi adalah bapaknya, dan seorang perempuan tadi adalah ibunya, sedangkan ia adalah anak dari kedua orang laki-laki dan perempuan tersebut. ${ }^{19}$

Dari uraian di atas secara sederhana anak diartikan sebagai seorang yang lahir akibat dari persetubuhan antara seorang laki-laki dan perempuan. Akan tetapi yang dimaksud penulis dalam artikel ini bukanlah anak sesuai dengan pengertian anak di atas. Ada beberapa pengklasifikasian tentang anak menurut golongan umurnya, karena usia anak akan berpengaruh terhadap bentuk perlindungan yang diberikan. Adapun anak menurut pembagian umurnya ada dua macam yaitu:

1. Anak belum dewasa.

2. Anak sudah dewasa.

Dalam Kompilasi Hukum Islam, disebutkan bahwa batas usia anak dianggap mampu berdiri sendiri atau dewasa adalah 21 (dua puluh satu) tahun. Sepanjang anak tersebut tidak bercacat fisik, maupun mental atau belum pernah melakukan perkawinan. Orang tuanya mewakili anak tersebut mengenai segala perbuatan hukum di dalam dan di luar pengadilan. ${ }^{20}$

\section{Pengertian Anak dalam UU NO. 23 Tahun 2002}

Anak adalah seorang laki-laki atau perempuan yang belum berusia 18 tahun dan belum memasuki masa pubertas selain itu anak merupakan generasi penerus bangsa yang menentukan berhasil atau tidak suatu bangsa. Anak merupakan karunia Tuhan Yang Maha Esa juga sebagai generasi muda yang menjanjikan karena dengan terbentuknya generasi muda yang idealis maka bangsa Indonesia pun akan ikut berkembang, maka dari itu pembinaan dari dini terhadap anak merupakan langkah utama bagi bangsa Indonesia untuk mewujudkan sumber daya manusia Indonesia yang berkualitas dan mampu memimpin serta memelihara Kesatuan Republik Indonesia sesuai dengan apa yang dijelaskan dan dipaparkan didalam Pancasila, selain itu juga dijelaskan dalam UndangUndang Nomor 3 Tahun 1997 mengatakan bahwa anak adalah bagian dari generasi muda sebagai salah satu sumber daya manusia yang merupakan potensi dan penerus cita-cita perjuangan bangsa yang

\footnotetext{
${ }^{19}$ Sajuti Thalib, Hukum Kekeluargaan Indonesia (Jakarta: Universitas Indonesia UI Press 1986), 132.

${ }^{20}$ Kompilasi Hukum Islam, Pasal 98 ayat 1,2.
} 
memiliki peran strategis dan mempunyai ciri-ciri dan sifat khusus memerlukan pembinaan perlindungan dalam rangka menjamin pertumbuhan dan perkembangan fisik, mental secara utuh serasi selaras dan seimbang.

Adapun kategori anak menurut Undang-Undang Nomor 23 Tahun 2002 adalah:"Anak adalah seorang yang belum berusia 18 (delapan belas) tahun termasuk anak yang masih dalam kandungan". ${ }^{21}$ Banyak anak yang bekerja demi membantu sistem perekonomian keluarga mereka padahal anak yang belum berumur di bawah 18 tahun tidak diperbolehkan untuk bekerja dengan alasan apapun seperti dalam Undang-Undang Nomor 23 Tahun 2002 pasal 66 ayat (3) yaitu: "Memanfaatkan, membiarkan, melakukan, menyuruh melakukan atau turut serta melakukan eksploitasi ekonomi atau seksual terhadap anak". ${ }^{22}$

Anak yang belum berusia 18 Tahun tidak boleh bekerja dengan alasan apapun karena mereka sebenarnya masuk kedalam kategori anak usia sekolah namun di Indonesia banyak anak usia sekolah bekerja di sector informal yang bekerja tanpa adanya kontrak tertulis serta jam kerja yang berlebihan bahkan sampai 8-9 jam perhari. Pekerja anak dimanapun mereka berada sebenarnya mengancam kehidupan masa depannya, termasuk masa depan keluarga serta masyarakat.

Menurut Undang-Undang Nomor 13 Tahun 2003 tentang ketenagakerjaan pasal 68 menyebutkan bahwa: "pengusaha dilarang untuk memperkerjakan anak, dan dalam pasal 69 juga menyebutkan bahwa pekerja dilarang memperkerjakan anak dibawah umur 18 tahun atau berusia 14-15 tahun untuk melakukan pekerjaan berat dan harus menerima upah sesuai dengan ketentuan yang berlaku". ${ }^{23}$

Undang-undang No. 23 tahun 2002, atau yang biasa diistilahkan dengan sebutan Undang-undang perlindungan anak, merupakan instrumen Nasional yang di bidang HAM dengan cakupan hak yang paling komprehensif. ${ }^{24}$ Terdiri atas sembilan puluh tiga pasal, Undangundang tersebut hingga saat ini dikenal sebagai satu-satunya konvensi di bidang HAM yang mencakupi baik hak-hak sipil dan politik maupun hak-hak ekonomi, sosial dan budaya, sekaligus. Beberapa persoalan

\footnotetext{
${ }^{21}$ Undang-Undang Republik Indonesia No. 23 Tahun 2002, Pasal 1 Ayat 1

${ }^{22}$ Undang-Undang Republik Indonesia No. 23 Tahun 2002, pasal 66 ayat 3

${ }^{23}$ Undang-Undang Republik Indonesia No. 13 Tahun 2002, Pasal 68,69

${ }^{24}$ Moch. Riza Zainal Abidin, Potret Anak dijawa Tengah Yayasan Setar (Semarang: Puspa Swara, 2003), 2
} 
hukum dalam Undang-undang perlindungan anak adalah:

a. Definisi anak adalah siapapun yang berusia di bawah 18 (delapan belas) tahun, terlepas mereka sudah menikah atau belum. Hal ini sesuai dengan definisi yang ada dalam Konvensi Hak Anak.

b. Dalam Undang-undang tersebut diatur tentang pembentukan Komisi nasional Perlindungan Anak dalam waktu satu tahun setelah Undang-undang disyahkan.

c. Dalam Undang-undang tersebut disebutkan bahwa pemerintah, penegak hukum, masyarakat, keluarga dan ornag tua merupakan pihak-pihak yang bertanggung jawab memberikan perlindungan kepada anak-anak.

d. Sanksi yang diberikan bagi mereka yang melakukan pelanggaran terhadap hak-hak anak. ${ }^{25}$

\section{Hukum Pekerja Anak di Sektor Informal dalam UU No. 23 Tahun 2002 dan UU No. 13 Tahun 2003}

Pengaturan tentang ketentuan anak bekerja, tidak diatur secara jelas dalam UU No. 23 Tahun 2002, tentang perlindungan anak. UU No.23 Tahun 2002, pasal 59, hanya menyebutkan bahwa "Pemerintah dan lembaga negara lainnya berkewajiban dan bertanggung jawab untuk memberikan perlindungan khusus kepada anak, dalam situasi darurat, anak yangt berhadapan dengan hukum, anak dari kelompok minoritas dan terisolasi, anak yang tereksploitasi secara ekonomi dan/atau seksual, anak yang diperdagangkan, anak yang menjadi korban penyalahgunaan narkotika, alkohol, psikotropika dan zat adiktif lainnya (Napza), anak korban penculikan, penjualan dan perdagangan, anak korban kekerasan baik fisik dan/atau mental, anak yang menyandang cacat, dan anak korban perlakuan salah dan penelantaran". ${ }^{26}$

Anak yang belum berusia 18 Tahun tidak boleh bekerja dengan alasan apapun karena mereka sebenarnya masuk kedalam kategori anak usia sekolah namun di Indonesia banyak anak usia sekolah bekerja di sector informal yang bekerja tanpa adanya kontrak tertulis serta jam kerja yang berlebihan bahkan sampai 8-9 jam perhari. Pekerja anak dimanapun mereka berada sebenarnya mengancam kehidupan masa

${ }^{25}$ Steven Allen, Kata Sambutan Perwakilan UNICEF Indonesia dalam Undang-undang No. 23 Tahun 2002 (Jakarta: Kementrian Pemberdayaan Perempuan Republik Indonesia \& Departemen Sosial republik Indonesia, 2002), 5-6.

${ }^{26}$ Undang-Undang Republik Indonesia No. 23 Tahun 2002, Pasal 59 
depannya, termasuk masa depan keluarga serta masyarakat.

\section{Syarat Mempekerjakan Anak}

Seorang pengusaha hendaknya dalam menghadapi anak baik yang datang sendiri atau yang diantar oleh orang tuanya, untuk meminta pekerjaan pada perusahaan nya, sebaiknya jika masih memungkinkan mencegah anak-anak itu bekerja di perusahaannya, atau jika naluri dan keadaan pengusaha itu mendorong, kalau mungkin atas pertimbangan yang matang sebaiknya menyatakan diri sebagai orang tua asuh bagi anak itu, sehingga mereka dapat lebih dipersiapkan untuk tenaga kerja yang cakap dan terampil untuk masa datang. ${ }^{27}$

Pada prinsipnya pengusaha dilarang mempekerjakan anak. Hal ini disebutkan dalam pasal 68 undang-undang nomor 13 tahun 2003 berbunyi: "Pengusaha dilarang mempekerjakan anak". Larangan mempekerjakan anak dimaksudkan untuk melindungi anak agar tidak terganggu pertumbuhan dan kesehatannya. Daya tahan tubuh anak masih sangat rentan terhadap lingkungan kerja, apabila sering berhubungan dengan bahan-bahan kimia. Larangan mempekerjakan anak ini dapat dikesampingkan jika anak yang bekerja tersebut berusia antara 13 (tiga belas) tahun hingga 15 (lima belas) tahun ${ }^{28}$, dan hanya melakukan pekerjaan ringan sepanjang tidak mengganggu perkembangan dan kesehatan anak secara fisik dan psikis.

Pengusaha diperbolehkan mempekerjakan anak, akan tetapi jika pengusaha tersebut telah melengkapi syarat-syarat antara lain sebagai berikut $^{29}$ :

a. Izin tertulis dari orang tua atau wali;

b. Perjanjian kerja antar pengusaha dengan orang tua atau wali;

c. Waktu kerja maksimum 3 (tiga) jam;

d. Dilakukan pada siang hari dan tidak mengganggu waktu sekolah;

e. Keselamatan dan kesehatan kerja;

f. Adanya hubungan kerja yang jelas; dan

g. Menerima upah sesuai dengan ketentuan yang berlaku.

Sedangkan pada pasal 70 diterangkan bahwa:

\footnotetext{
${ }^{27}$ G. Kartasapoetra, Hukum Perburuhan dDi Indonesia Berlandaskan Pancasila (Jakarta: Sinar Grafika, 1994), 40

${ }^{28}$ Undang-undang Republik Indonesia, No. 13 tahun 2003 tentang Tenaga Kerja, Pasal 68

${ }^{29}$ Ibid.
} 
a. Ayat (1)

"Anak dapat melakukan pekerjaan yang merupakan bagian dari kurikulum pendidikan atau pelatihan yang disyahkan oleh pejabat berwenang",

b. Ayat (2)

"Anak sebagaimana dimaksud pada ayat (1)paling sedikit berumur 14 (empat belas) tahun",

c. Ayat (3)

"Pekerjaan sebagaimana dimaksud pada ayat (1) dapat dilakukan dengan syarat :

1. Diberi petunjuk yang jelas tentang cara pelaksanaan pekerjaan serta bimbingan dan pengawasan dalam melaksanakan pekerjaan; dan

2. Diberi perlindungan keselamatan dan kesehatan kerja”

Menurut Undang-undang No 13 Tahun 2003, tempat yang dianggap masih layak untuk digunakan anak bekerja, antara lain;

a. Tempat kerja yang merupakan bagian dari kurikulum pendidikan atau pelatihan yang disahkan oleh pejabat yang berwenang.

b. Dalam hal anak yang dipekerjakan bersama-sama dengan pekerja/buruh dewasa, maka tempat kerja anak harus dipisahkan dari tempat kerja pekerja/buruh dewasa" ${ }^{30}$

\section{Pengertian Pekerja Sektor Informal}

Perekonomian di kebanyakan negara berkembang bahkan di beberapa negara maju adalah fenomena jumlah dan tingginya peningkatan penduduk yang bekerja di sektor informal. Hal ini didorong oleh tingkat urbanisasi yang tinggi dimana penawaran pasar tenaga kerja mampu direspon oleh permintaan tenaga kerja sektor informal. Definisi sektor informal adalah tenaga kerja yang bekerja pada segala jenis pekerjaan tanpa ada perlindungan negara dan atas usaha tersebut tidak dikenakan pajak. Definisi lainnya adalah segala jenis pekerjaan yang tidak menghasilkan pendapatan yang tetap, tempat pekerjaan yang tidak terdapat keamanan kerja (job security), tempat bekerja yang tidak ada status permanen atas pekerjaan tersebut dan unit usaha atau lembaga yang tidak berbadan hukum. Sedangkan ciri-ciri kegiatan-kegiatan informal adalah mudah masuk, artinya setiap orang dapat kapan saja

\footnotetext{
${ }^{30}$ Undang-undang Republik Indonesia No. 13 tahun 2003, Pasal 70 ayat 10, 2
} 
masuk ke jenis usaha informal ini terutama dalam kasus ini adalah anak, bersandar pada sumber daya lokal, biasanya usaha milik keluarga, operasi skala kecil, padat karya, keterampilan diperoleh dari luar sistem formal sekolah dan tidak diatur dan pasar yang kompetitif. Contoh dari jenis kegiatan sektor informal antara lain pedagang kaki lima (PKL), becak, penata parkir, pengamen dan anak jalanan, pedagang pasar, buruh tani dan lainnya. ${ }^{31}$

\section{Kasus Pekerja Anak di Sektor Informal}

Kasus pekerja anak memang semakin marak bahkan menjurus ke perbudakan cintohnya saja di Kampung Bayur Opak, Desa Lebak Wangi, Kecamatan Sepatan Timur, Tangerang, Banten. terbongkar praktik perbudakan buruh yang bekerja di sebuah industri rumahan pengolahan limbah menjadi perangkat dapur berupa wajan dan kuali aluminium berbendera CV. Sinar Logam. Dalam peristiwa itu ada 34 korban buruh dan polisi mengamankan lima orang tersangka. Dari sejumlah buruh itu diketahui delapan orang berasal dari Lampung, seorang dari Sukabumi, seorang dari Bandung, dan sisanya dari Cianjur. Sedang yang menjadi tersangka adalah pemilik CV Sinar Logam, yakni Yuki Irawan (41), Sudirman (34), Nurdin (34), Jaya alias Mandor (41), dan, Tedi Sukarno (34) tangan kanan Yuki. Sementara dua tersangka lainnya, sedangkan Tio dan Jack masih buron. Tersangka dikenakan Pasal 333 KUHP tentang perampasan kemerdekaan dengan ancaman hukuman 8 tahun, dan Pasal 351 KUHP tentang penganiayaan dengan ancaman hukuman 5 tahun. Pengenaan pasal itu sesuai dengan beberapa temuan, antara lain, pemilik pabrik tak membayar gaji sebagian besar buruh, tidak memberikan fasilitas hidup yang layak, tidak mengizinkan buruh melakukan sembahyang, tidak memperbolehkan buruh istirahat serta melakukan penganiayaan. Pengenaan pasal terhadap tersangka masih dimungkinkan akan berkembang. Pelaku dikenakan pasal secara kumulatif. Yaitu pengenaan pasal yang termaktup dalam UndangUndang Nomor 39 tahun 1999 Tentang Hak Asasi Manusia, UndangUndang Nomor 13 Tahun 2003 Tentang Ketenagakerjaan dan UndangUndang Nomor 26 Tahun 2000 Tentang Pengadilan HAM. Bahkan perlu pengenaan pasal yang termaktup dalam Undang-Undang Nomor 23 Tahun 2003 tentang perlindungan anak. "Karena dalam kasus

\footnotetext{
${ }^{31}$ Hendri Saparini dan M. Chatib Basri, Pekerja sektor informal(Jakarta: FH UI,1991), 2
} 
perbudakan Tengerang ini pemilik pabrik juga mempekerjakan tenaga kerja di bawah umur,"32

Yang dimaksud bekerja, atau dipekerjakan dalam hal ini adalah bekerja dalam arti yang ringan sesuai dengan kemampuan si anak. Seperti yang dimaksudkan dalam pasal 69 ayat (1) yang berbunyi;

"Ketentuan sebagaimana yang dimaksud pasal 68 dapat dikecualikan bagi anak berumur antara 13 (tiga belas) tahun sampai dengan 15 (lima belas) tahun untuk melakukan pekerjaan ringan sepanjang tidak mengganggu perkembangan dan kesehatan fisik, mental dan sosial".

Dengan demikian yang menjadi pedoman jenis pekerjaan yang dapat dengan terpaksa diberlakukan pada anak, adalah jenis pekerjaan yang ringan dan menyesuaikan kemampuan anak dan kebutuhan untuk perkembangan anak.

Pengaturan terhadap pelarangan mempekerjakan anak pada jenis pekerjaan yang berbahaya, ditegaskan oleh pemerintah dengan memberikan himbauan, yakni bahwa siapapun (termasuk pengusaha) dilarang mempekerjakan dan melibatkan anak pada pekerjaanpekerjaan terburuk. ${ }^{33}$

Secara umum, anak yang tidak diperbolehkan menjalankan pekerjaan pada beberapa tempat tertentu, antara lain $^{34}$ :

1. Di pabrik-pabrik, yaitu pada ruangan yang tertutup atau yang dipandang sebagai tertutup, dimana digunakan satu alat atau lebih yang digerakkan dengan tenaga mesin,

2. Di tempat-tempat kerja yaitu pada ruangan yang tertutup dimana biasanya pada ruangan-ruangan tersebut dilakukan pekerjaanpekerjaan tangan secara bersama-sama oleh sepuluh pekerja atau lebih,

3. Di tempat-tempat tertentu di mana dilakukan pembuatan, pemeliharan, pembetulan atau pembongkaran suatu bangunan di bawah tanah, pekerjaan galian, bangunan air, gedung dan jalan,

4. Pada perusahaan kereta api,

5. Pada pemuatan, pembongkaran dan pemindahan barang, baik di pelabuhan, dermaga dan galangan, maupun di stasiun tempat

32 Cahyo Sudaso, "Kasus Perbudakan di Pabrik Panci Tangerang", http://indiependen.com, (6 Februari 2014),

${ }^{33}$ Undang-undang nomor 13 tahun 2003 tentang Ketenagaqkerjaan, Pasal 74 ayat 1.

${ }^{34}$ G. Kartasapoetra, Hukum Perburuhan di Indonesia Berlandaskan Pancasila, 41. 
pemberhentian dan tempat pembongkaran dan tempat penumpukan barang atau gudang-gudang yang dalam hal ini dikecualikan jika barang-barangnya merupakan barang-barang jinjingan dan tidak terlalu berat.

Selanjutnya, bagi para pihak pengusaha tidak dibenarkan mempekerjakan anak pada jenis pekerjaan di bidang pertambangan, daerah atau ruang bawah tanah, tempat pengambilan logam dan bahan-bahan lainnya dari sumbernya di dalam tanah, karena pekerjaan demikian dapat mengganggu kesehatan dan keselamatannya. ${ }^{35}$

Kondisi faktual berdasarkan hasil penelitian, rata-rata pengusaha sektor informal tidak menetapkan jadwal jam kerja, kecuali jam mulai bekerja, yaitu berkisar antara jam 07.00 WIB atau jam 08.00 WIB, namun selesainya tidak menentu, bahkan ada yang tergantung pekerjaan, seperti pedagang asongan minuman dan makanan kecil, kecenderungan pekerja anak ini apabila menjual barang dagangannya seperti ini menunggu sampai barang dagangannya habis atau paling tidak sisa dagangannya tidak banyak, karena penghasilannya juga akan sedikit dan tidak jarang dimarahi oleh pemilik dagangan.

Selain ketentuan-ketentuan di atas, sesungguhnya jika meninjau lebih dalam, bagi anak-anak yang dipekerjakan pada perusahaanperusahaan, sebaiknya tidak diserahi tugas yang sangat memerlukan ketelitian dan keamanan. Semisal menjadi penjaga tiket. Dari segi ketelitian, anak-anak cenderung kurang dan bahkan ceroboh. Dari segi keamanan, tentunya sangat berbahaya, karena anak-anak yang mengemban tugas demikian akan selalu menjadi incaran orang yang kurang memiliki rasa kemanusiaan.

Sedangkan yang termasuk Pekerjaan-pekerjaan yang terburuk, yang meliputi;

a. Segala pekerjaan dalam bentuk pekerjaan atau sejenisnya;

b. Segala pekerjaan yang memanfaatkan, menyediakan atau menawarkan anak untuk pelacuran, produksi pornografi, pertunjukan porno atau perjudian;

c. Segala pekerjaan yang memanfaatkan, menyediakan atau melibatkan anak untuk produksi dan perdagangan minuman keras, narkotika, psikotropika dan zat adiktif lainnya; dan atau

d. Semua pekerjaan yang membahayakan terutama bagi kesehatan,

${ }^{35}$ Ibid, 43. 
keselamatan atau moral anak". ${ }^{36}$

\section{Bentuk-Bentuk Perlindungan Terhadap Anak dan Sanksi Pidana}

Anak-anak, seperti halnya orang dewasa, mempunyai hak atas hak asasi dasar manusia. Namun, karena kebutuhan mereka, hak-hak anak perlu diperhatikan dan diperlakuan secara khusus. Konvensi hak- hak anak dirancang untuk menegakkan dan menjaga hak-hak anak. Hak-hak anak tersebut termasuk: (1) Hak-untuk kelangsungan hidup; (2) Hakhak untuk tumbuh kembang; (3) Hak-hak untuk dilindungi; dan (4) Hak-hak untuk berpartisipasi. Dalam koridor tersebut, terhadap anak tidak dibenarkan adanya perbuatan yang dapat menghambat pertumbuhan dan perkembangan. Seorang anak yang tidak dapat diasuh dengan baik oleh orang tuanya dapat mengakibatkan pembatalan hak asuh orang tua. ${ }^{37}$

Upaya-upaya dalam rangka perlindungan hukum tersebut dilakukan dengan melakukan ratifikasinya terhadap Konvensi Hak Anak yang diwujudkan ke dalam Undang-undang nomor 23 tahun 2002 tentang perlindungan anak, yang dengan jelas menegaskan kewajiban pemerintah untuk melakukan perlindungan secara khusus terhadap anak dalam situasi darurat. Peraturan ini secara eksplisit menyadari bahwa pentingnya upaya negara untuk memberikan perlindungan kepada anak-anak. Sebagaimana terdapat dalam:

Pasal 20: "Negara, pemerintah, masyarakat, keluarga dan orang tua berkewajiban dan bertanggung jawab terhadap penyelenggaraan perlindungan anak", dan pasal 22, "Negara dan pemerintah berkewajiban dan bertanggung jawab memberikan dukungan sarana dan prasarana dalam penyelenggaraan perlindungan anak"38

Dengan demikian negara atau pemerintah berkewajiban untuk melakukan perlindungan terhadap anak dan bertanggung jawab memberikan sarana dan prasarana dalam penyelenggaraan perlindungan tersebut.

Sanksi-sanksi pidana yang dicantumkan dalam beberapa pasal antara lain;

\footnotetext{
${ }^{36}$ Undang-undang No. 13 tahun 2003 tentang Ketenagakerjaan, Pasal 74 ayat 2.

${ }^{37}$ M. Ghufron, Pekerja Anak Bermasalah (Semarang: Puspa Swara, 2001,) 33.

${ }^{38}$ Undang-undang Republik Indonesia No. 23 tahun 2002, Pasal 20
} 
a) Pasal 77

"Setiap orang yang melakukan penelantaran yang mengakibatkan anak mengalami sakit atau penderitaan, baik fisik, mental, maupun sosial, dipidana penjara paling lama 5 tahun dan/atau denda paling banyak Rp. 100000000 (seratus juta)".

b) Pasal 78

"Setiap orang yang mengetahui dan sengaja membiarkan anak dalam situasi darurat, anak yang behadapan dengan hukum, anak dari kelompok minoritas terisolasi, anak yang tereksploitasi secara ekonomi dan/atau seksual, anak yang diperdagangkan, anak yang menjadi korban penyalahgunaan narkotika, alkohol, psikotropika, dan zat adiktif lainnya (napza), anak korban penculikan, anak korban perdagangan, anak korban kekerasan, padahal anak tersebut memerlukan pertolongan dan harus dibantu, dipidana dengan pidana penjara paling lama 5 (lima) tahun dan/atau denda paling banyak Rp. 100000000 (seratus juta)”.

c) Pasal 80Ayat (1)

"Setiap orang yang melakukan kekejaman, kekerasan atau ancaman kekerasan, atau penganiayaan terhadap anak, dipidana dengan pidana penjara paling lama 3 (tiga) tahun 6 (enam) bulan dan/atau denda paling banyak Rp. 72000000 (tujuh puluh dua juta)". Ayat (2) "Jika anak yang jadi korban mengalami luka berat, maka pelaku dipidana dengan pidana penjara paling lama 5 (lima) tahun dan/atau denda paling banyak Rp. 100000000 (seratus juta)". ayat (3) "Dalam hal anak yang jadi korban meninggal, maka pelaku dipidana dengan pidana penjara paling lama 10 (sepuluh) tahun dan/atau denda paling banyak Rp. 200000000 (dua ratus juta)". Ayat (4) "Pidana ditambah sepertiga dari ketentuan apabila yang melakukan penganiayaan tersebut adalah orang tuanya”.

d) Pasal 81

"Setiap orang yang dengan sengaja melakukan kekerasan atau ancaman kekerasan memaksa anak melakukan persetubuhan dengannya atau dengan orang lain, dipidana dengan pidana penjara paling lama 15 (lima belas) tahun dan paling singkat 3 (tiga) tahun dan denda paling banyak Rp. 
300000000 (tiga ratus juta) dan paling sedikit Rp. 60 000000 (enam puluh juta)".

e) Pasal 82

"Setiap orang yang dengan sengaja melakukan kekerasan atau ancaman kekerasan, memaksa, melakukan tipu muslihat, serangkaian kebohongan membujuk anak untuk melakukan atau membiarkan dilakukan perbuatan cabul, dipidana denga pidana penjara paling lama 15 (lima belas) tahun dan paling singkat 3 (tiga) tahun dan denda paling banyak Rp. 300000000 (tiga ratus juta) dan paling sedikit Rp. 60000000 (enam puluh juta)".

f) Pasal 83

"Setiap orang yang memperdagangkan, menjual atau menculik anak untuk diri sendiri atau untuk dijual, dipidana dengan pidana penjara paling lama 15 (lima belas) tahun dan paling singkat 3 (tiga tahun) dan denda paling banyak Rp. 300000000 (tiga ratus juta) dan paling sedikit RP. 60 000000 (enam puluh juta)".

g) Pasal 88

"Setiap orang yang mengeksploitasi ekonomi atau seksual anak dengan maksud untuk menguntungkan diri sendiri atau orang lain dipidana dengan pidana penjara paling lama 10 (sepuluh) tahun dan/atau denda paling banyak Rp. 200000 000 (dua ratus juta)".

Pasal-pasal yang berkaitan dengan sanksi tersebut memberikan gambaran bahwa pemerintah menunjukkan keseriusan dan komitmennya untuk benar-benar melakukan perlindungan terhadap anak. Atau dengan kata lain dapat diartikan bahwa, perlindungan anak secara yuridis sudah tertuang dalam UU No 23 Tahun 2002 yang juga mengatur tentang pemberian sanksi terhadap hal-hal yang berimplikasi pada kerugian yang dialamai oleh anak, seperti kekerasan, perdagangan dan lain-lain, dengan bentuk sanksi yang berupa tahanan maupun dendan yang cukup besar.

\section{Batasan Umur Anak Bekerja}

Para ulama dalam ijtihadnya telah merumuskan beberapa syarat dan rukun tenaga kerja, di antara persyaratan tersebut salah 
satunya menyebutkan bahwa orang yang melakukan akad (pengusaha dan pekerja), disyaratkan kedua belah pihak harus sudah baligh, berakal serta mempunyai ahliyah (kecakapan) agar dalam pelaksanaannya terjadi atas dasar kerelaan, tanpa ada unsur paksaan dan tidak ada unsur garar (penipuan). Menurut Ulama Ushul, ahliyah (cakap) dibagi menjadi dua bagian:

Pertama, ahliyah al-wujûb, yaitu kepantasan seseorang untuk diberi hak dan kewajiban. Ahliyah al-wujûb, dibagi menjadi dua: a. Ahliyah al-wujûb sempurna, yaitu seseorang yang sudah pantas menerima hak dan kewajiban. Keadaan ini dimiliki oleh manusia sejak lahir sampai ia meninggal dunia. Misalkan seorang anak kecil dikenakan wajib zakat, karena ia belum dewasa maka yang melaksanakannya adalah orang tua atau walinya, dan dia punya hak waris atas harta yang ditinggalkan oleh orang tua atau walinya..$^{39}$ b. Ahliyah al-wujûb Kurang Sempurna, Yaitu kondisi seseorang yang hanya mampu menerima hak.

Kedua, ahliyatul adâ', yaitu kepantasan seseorang dipandang sah atas segala perkataan dan perbuatannya. Seperti misalnya ketika ia melakukan perjanjian atau perikatan, tindakan-tindakannya dianggap sah dan mempunyai akibat hukum. ${ }^{40}$ Ahliyatul adâ' dibagi menjadi tiga:

a. Ada kalanya seseorang tidak mempunyai ahliyatul adâ' (kecakapan berbuat) sama sekali, atau kehilangan kecakapan berbuat, misalnya anak kecil, karena dia tidak mempunyai ahliyatul adâ', maka segala tindakannya tidak berpengaruh dalam shara', sehingga segala sesuatu yang berbentuk perikatan mu'amalahnya dianggap tidak syah dan batal.

b. Keadaan seseorang yang mempunyai ahliyatul adâ' namun kurang sempurna, seperti hal anak yang sudah mumayyiz, akan tetapi belum mencapai kondisi kedewasaan.

c. Ahliyatul adâ' sempurna, yakni kondisi seseorang yang sudah mencapai kedewasaan dan dapat berfikir secara sempurna, maka segala tindakan mu'amalahnya dianggap sah, karena sudah râshid (dapat berfikir dengan cerdas). ${ }^{41}$

Anak di bawah umur 18 (delapan belas) tahun adalah kondisi di mana seseorang dianggap belum mampu mengendalikan harta benda

\footnotetext{
${ }^{39}$ Mukhtar Yahya, Dasar-dasar Pembinaan Hukum Islam (Bandung: al-Ma'arif, t.th), 166.

40 Ibid., 165.

${ }^{41}$ Abdul Wahab Khallaf, Ilmu Ushul Figh (Semarang: Dina Utama Semarang, 1994), 137.
} 
yang dimilikinya. Keadaan ini juga merupakan masa seseorang belum bisa bertanggung jawab atas segala perbuatannya dan belum dapat membedakan mana yang baik dan mana yang buruk. Masa ini pada umumnya adalah masa belum sempurnanya pikiran seseorang. ${ }^{42}$

Maka dengan demikian anak merupakan orang yang masih dalam pengampuan wali. Ia tidak sah melakukan transaksi harta miliknya sendiri, apalagi melakukan tindakan yang melibatkan orang lain misalnya perjanjian kerja. Menurut golongan Syafi'iyah, ada beberapa orang yang tidak diperkenankan melakukan perjanjian kerja, termasuk di dalamnya anak- anak, sebagaimana diterangkan dalam kitab al-Fiqh 'Alâ Madhâhib al-Arba'ah;

"Golongan Syafi'iyah berpendapat, ada empat orang yang tidak dapat (tidak sah) melakukan suatu perjanjian (termasuk perjanjian kerja), mereka itu adalah: anak kecil, baik sudah mumayyiz atau belum, orang gila, hamba sahaya walaupun sudah mukallaf, dan orang buta. Apabila mereka melakukan suatu perjanjian maka hukumnya tidak sah.”33

Dari pendapat ulama Syafi'iyah di atas, maka dapat dipahami tentang tidak diperbolehkannya anak kecil melakukan suatu perjanjian kerja atau bekerja, karena anak kecil belum dapat berfikir secara matang dan baik, sehingga tindakannya belum dapat dipertanggungjawabkan. Menurut syari'at Islam, pertanggungjawaban seseorang atas perbuatannya didasarkan pada dua hal, yang pertama kekuatan dan kemampuan berfikir, kedua atas pilihan sendiri (iradah dan ikhtiar). Oleh karena itu, kedudukan anak berbeda-beda menurut perbedaan masa yang dilaluinya dalam lingkungan kehidupan yang ia jalani, mulai dari waktu melahirkan, sampai pada masa memiliki dua perkara tersebut. Menurut pendapat para fuqaha, kedudukan anak berdasarkan perbedaan masa yang dilaluinya terdiri dari tiga bagian:

a. Masa tidak adanya kemampuan berfikir. Masa ini dimulai sejak dia dilahirkan sampai ia berusia sekitar7 (tujuh) tahun. Pada masa tersebut, anak belum mempunyai kemampuan berfikir dan disebut anak yang belum mumayyiz. Sebenarnya kemampuan berfikir tidak terbatas pada usia tertentu, sebab kadang-kadang dapat timbul sebelum usia 7 (tujuh) tahun, kadang-kadang juga terlambat,

\footnotetext{
${ }^{42}$ Ibid., 95.

${ }^{43}$ Abdur Rahmanl al-Jaziry, al-Figh 'Alâ Madhâhib al-'Arba'ah (Mesir: al-Maktabah al- Tijariah, t. th) 160 .
} 
tergantung dari perbedaan orang, lingkungan, keadaan dan mental psikisnya.

b. Masa kemampuan berfikir lemah. Masa ini dimulai sejak usia 7 (tujuh) tahun, sampai mencapai usia dewasa dan kebanyakan fuqaha membatasi dengan usia 15 (lima belas) tahun, kalau anak sudah mencapai usia itu, ia dianggap sudah dewasa.

c. Masa kemampuan berfikir penuh. Masa ini dimulai sejak anak mencapai usia kecerdikan atau setelah mencapai usia 15 (lima belas) tahun ke atas. ${ }^{44}$

Satu tingkat di atas mumayyiz adalah baligh, yaitu fase transisi yang bersifat alami dilalui oleh manusia. Masa ini merupakan masa beralihnya sifat kekanak-kanakan menuju kondisi dewasa dan pada masa inilah seseorang mulai terkena beban taklif syara' dan akan bertanggung jawab atas segala tindakannya. Oleh karena itu, semua fuqaha sepakat seseorang yang telah baligh terkena khitab shara'. Baligh bisa diketahui dari dua aspek, pertama aspek biologis, kedua aspek usia.

Baligh dari aspek biologis ditandai dengan ihtil bagi pria dan haid bagi wanita, selain itu baligh secara biologis dapat juga ditandai dengan tumbuhnya rambut kasar di sekitar qubul. ${ }^{45}$ Sedangkan baligh menurut segi usia minimal 12 (dua belas) tahun bagi laki-laki, dan minimal 9 (sembilan) tahun bagi perempuan. Pada usia inilah seseorang mengalami baligh dari segi usia. Apabila pada usia tersebut belum muncul tanda ihtilâm atau haid, maka fase baligh dari segi umur ditunggu sampai 15 (lima belas) tahun. ${ }^{46}$

Pada dasarnya, taklif shara' tidak didasarkan pada batasan usia secara jelas, akan tetapi melalui dari munculnya kekuatan yang sempurna yaitu kekuatan biologis dan kekuatan akal. Unsur kekuatan biologis tampak dirasakan dalam hal-hal yang dapat dimaklumi secara tradisi, baik baligh dari segi tindakan atau dari segi hukum. Keadaan ini dapat diprediksi berdasarkan pengalaman yang sering terjadi, atau kebiasaan yang berlaku. Sedangkan kemampuan akal dapat dilihat dari indikasi perimbangan perbuatannya, indikasi ini tidak dapat dirasakan dari segi biologis. Walaupun kondisi itu dijadikan dasar terhadap adanya

\footnotetext{
${ }^{44}$ Ahmad Hanafi, Azaz-Azaz Hukum Pidana Islam (Jakarta: Bulan Bintang, 1976), 370.

45 Ibid, 514.

46 Ibid, 516.
} 
taklif, namun dinyatakan secara implisit. Kondisi baligh itu merupakan praduga yang nyata menurut tradisi pertumbuhan intelegensi sebagaimana yang terjadi pada pertumbuhan biologis. ${ }^{47}$

Berdasarkan keterangan di atas, maka bahwa batasan umur anak diperbolehkan bekerja ketika ia berumur di atas 15 tahun, atau telah matang secara akal, artinya daya intelegensi anak tersebut memungkinkan ia untuk melakukan suatu perjanjian kerja atau melakukan pekerjaan. Adat atau 'urf yang di dalam terminologi ilmu fiqh adalah tindakan-tindakan atau tingkah laku dari suatu kelompok masyarakat yang dianggap baik, dan dilakukan secara terus menerus sehingga akhirnya menjadi suatu kebiasaan, maka dengan sendirinya ia akan menjadi norma dalam masyarakat, yang pada perkembangannya menjadi norma hukum. ${ }^{48}$

Menurut Abdul Wahab Khallaf, 'urf dibagi menjadi dua bagian, yaitu; 'urf sahîh, Yaitu suatu kebiasaan yang sudah dikenal oleh masyarakat luas yang pelaksanaannya tidak bertentangan dengan syariat Islam dan tidak menimbulkan mafsadah. 'Urf fâsid, yaitu suatu kebiasaan yang sudah dikenal masyarakat ramai dan pelaksanaannya bertentangan dengan syariat Islam, karena mengandung mudarat bagi manusia dan melupakan aspek maslahah. Seperti transaksi yang mengandung unsur riba atau sejenisnya yang pada prinsipnya dikecam oleh syariat Islam. ${ }^{49}$

Dari uraian tersebut, tampaknya pekerjaan yang dilakukan oleh anak-anak di bawah 18 tahun dapat masuk dalam kategori 'urf sahîh. Pekerjaan yang dilakukan oleh anak-anak dapat termasuk kriteria 'urf sahîh, karena pekerjaan tersebut dilakukan terus menerus dan berulang-ulang, dari generasi ke generasi, serta memenuhi kriteria 'urf sahîh, artinya tidak membatalkan yang halal dan menghalalkan yang haram. Dalam sejarah tercatat bahwa dahulu saat masih kecil, pernah juga Nabi Muhammad bekerja, ketika Nabi berumur 12 tahun, mengikuti pamannya Abu Thalib yang berniaga membawa barang dagangan dari Makkah ke Syam. Selain itu, Nabi juga bekerja menggembala kambing, baik kambing milik keluarga maupun kambing milik tetangga yang dipercayakan untuk digembalakannya. Nabi dalam

\footnotetext{
47 Ibid, 517.

${ }^{48}$ Mukhtar Yahya, Dasar-dasar Pembinaan Hukum Islam, 157.

${ }^{49}$ Abdul Wahab Khallaf, Ilmu Ushul Figh, 89
} 
menggembala kambing benar-benar bekerja dengan motivasi upah untuk pemenuhan kebutuhan hidupnya.

Secara sederhana, dapat dikatakan bahwa anak bekerja adalah wajar sejak masa Nabi. Akan tetapi perlu memperhatikan secara lebih lanjut, motivasi, apa dan bagaimana syarat-syarat mempekerjakannya, agar hak-hak tidak terlupakan. Di sisi lain, kemaslhatan yang timbul dari anak bekerja dapat membantu meringankan beban perekonomian keluarganya, untuk biaya sekolah mereka, dan untuk biaya keperluan lain.

\section{Pidana Mempekerjakan Anak}

Jadi di dalam Islam juga di atur bahwa ketika anak belum memenuhu syarat untuk bekerja atau belum mampu untuk menjalankan pekerjaan maka semua itu menjadi larangan bagi siapapun yang akan mempekerjakan anak di bawah umur dan Islam menjelaskan terhadap tindak pidana yang merugikan orang lain terutama dalam hal ini adalah anak, kejahatan ini dapat di kategorikan sebgai jarîmah. Jarîmah sendiri ada beberapa kategori yang meliputi: ${ }^{50}$ Dilihat dari segi berat ringannya hukuman, jarîmah dibagi tiga,
a. Jarîmah hudûd
b. Jarîmah qisâs diyât
c. Jarîmah ta'zîr
d. Jarîmah hudûd

1) Jarîmah hudûd adalah bentuk jamak dari had artinya batas, menurut syara' (istilah fiqh) artinya batas-batas (ketentuanketentuan) dari Allah tentang hukuman yang diberikan kepada orang-orang yang berbuat dosa.

2) Jarîmah qisâs diyât adalah bentuk masdar, sedangkan asalnya adalah qassa yang artinya memotong. Asal dari kata iqtassa yang artinya mengikuti perbuatan si pelaku sebagai balasan atas perbuatannya. ${ }^{51}$ Qisâs juga bermakna hukum balas (yang adil) atau pembalasan yang sama yang telah dilakukan. Si pembunuh harus direnggut nyawa sebagaimana dia mencabut nyawa korban. Hukuman qisâs dibagi dua macam, yaitu: ${ }^{52}$ Qisâs jiwa, yaitu hukum bunuh bagi tindak

\footnotetext{
${ }^{50}$ Makrus Munajat, Hukum Pidana Islam di Indonesia, 12.

${ }^{51}$ Marsum, Jinayah Hukum Pidana Islam, 144.

${ }^{52}$ Said Aqil Al Munawar, Hukum Islam \& Pluralitas Sosial, 62.
} 
pidana membunuh, Qisâs pelukaan, yaitu untuk tindak pidana menghilangkan anggota badan, kemanfaatan atau pelukaan anggota badan. ${ }^{53}$

3) Jarîmah ta'zîr, yaitu jarîmah yang diancam hukuman ta'zîr (pengajaran atau ta'dzib dalam artian sendiri). Semua macam jarîmah selain jarîmah hudûd dan qisâs-diyât termasuk jarîmah ta'zîr, jadi jumlahnya banyak jenisnya dan bermacam-macam hukumanya dari yang ringan sampai dengan yang berat. Syara' tidak menentukan macam-macam perbuatan yang diancam hukuman ta'zîr dan syara' juga tidak menentukan macam hukuman yang diancamkan. Dalam menetapkan jarîmah ta'zîr, prinsip utama yang menjadi acuan penguasa adalah menjaga kepentingan umum dan melindungi setiap anggota masyarakat dari kemudharatan (bahaya). Di samping itu, penegakkan jarîmah ta'zîr harus sesuai dengan prinsip shar' $i .{ }^{54}$

Dari sini sudah jelas bahwa hukum mempekerjakan anak di bawah umur termasuk dalam kategori jarîmah ta'zîr, karena hukuman dalam jarîmah ta'zîr di tentukan oleh pemerintah yang berkuasa karena hukum mempekerjakan anak di bawah umur tidak di atur secara rinci dalam hukum islam. Hukuman-hukuman ta'zîr banyak jumlahnya, yang dimulai dari hukuman paling ringan sampai hukuman yang terberat. Hakim diberi wewenang untuk memilih di antara hukuman-hukuman tersebut, yaitu hukuman yang sesuai dengan keadaan jarîmah serta diri pembuatnya. Hukuman-hukuman ta'zîr ditinjau dari segi tempat dilakukannya hukuman, yaitu :

a. Hukuman badan, yaitu yang dijatuhkan atas badan seperti hukuman mati, dera, penjara dan sebagainya.

b. Hukuman jiwa, yaitu dikenakan atas jiwa seseorang, bukan badannya, seperti ancaman, peringatan dan teguran.

c. Hukuman-harta, yaitu yang dikenakan terhadap harta seseorang, seperti diyât, denda dan perampasan harta. ${ }^{55}$

Jarîmah ta'zîr ialah memberi pelajaran, artinya suatu jarîmah yang diancam dengan hukuman ta'zîr yaitu hukuman selain hadd dan qisâs. Jarîmah ini untuk menentukan ukuran atau batas hukumannya di

\footnotetext{
${ }^{53}$ Marsum, Jinayah Hukum Pidana Islam, 164.

${ }^{54}$ Ibid., 8.

${ }^{55}$ Ahmad Hanafi, Asas-asas Hukum Pidana Islam, 262.
} 
pegang penuh oleh otoritas pemerintah dalam hal ini hakim. ${ }^{56}$ seperti kasus pekerja anak ini termasuk dalam jarîmah ta'zîr karena tidak di atur dalam islam secara langsung dan wewenang sepenuhya di kembalikan kepada pemerintah. Semua perbuatan tersebut sangat dilarang oleh Islam karena dapat merusak tananan kehidupan berbangsa dan bernegara.

\section{Perlindungan Hukum terhadap Pekerja Anak di Sektor informal dalam Perspektif Figh dan Unaang-Undang No. 23 tahun 2002 tentang perlindungan anak}

Pengaturan tentang ketentuan anak bekerja, tidak diatur secara jelas atau detail dalam UU No. 23 Tahun 2002 tentang Perlindungan Anak. UU No.23 Tahun 2002, pasal 59, hanya menyebutkan bahwa:

"Pemerintah dan lembaga negara lainnya berkewajiban dan bertanggung jawab untuk memberikan perlindungan khusus kepada anak, dalam situasi darurat, anak yangt berhadapan dengan hukum, anak dari kelompok minoritas dan terisolasi, anak yang tereksploitasi secara ekonomi dan/atau seksual, anak yang diperdagangkan, anak yang menjadi korban penyalahgunaan narkotika, alkohol, psikotropika dan zat adiktif lainnya (Napza), anak korban penculikan, penjualan dan perdagangan, anak korban kekerasan baik fisik dan/atau mental, anak yang menyandang cacat, dan anak korban perlakuan salah dan penelantaran" $" 57$.

Karena keterbatasan pengaturan ketentuan tentang anak bekerja dalam UU No.23 Tahun 2003, dan untuk memperkuat data tentang ketentuan anak bekerja, penulis mengemukakan ketentuan tentang anak bekerja sesuai dengan UU No. 13 Tahun 2003 tentang Ketenagakerjaan.

Pengusaha, pada dasarnya dilarang mempekerjakan anak, hal ini tercantum di dalam ketentuan Pasal 68 UU Ketenagakerjaan. Namun demikian, ketentuan Pasal 69 ayat (2) memberikan pengecualian, yaitu bahwa mempekerjakan anak boleh dilakukan asalkan dipenuhi syaratsyarat sebagaimana diatur di dalam ketentuan Pasal tersebut. Dalam praktek hubungan kerja antara pengusaha dan pekerja anak ditemukan beberapa bentuk penyimpangan persyaratan kerja sebagaimana ditentukan pada Pasal 69 ayat (2) UU Ketanagakerjaan. persyaratan

\footnotetext{
${ }^{56}$ Makhrus Munajat, Hukum Pidana Islam di Indonesia, 15.

${ }^{57}$ Undang-undang No. 23 Tahun 2002 Tentang Perlindungan Anak, Pasal 59.
} 
sebagaimana diatur dalam ketentuan Pasal 69 ayat (2) UU Ketenagakerjaan sebagaimana terurai di bawah ini.

Pertama, tidak ada izin tertulis orang tua/wali. Persyaratan sebagaimana ditentukan dalam ketentuan Pasal 69 ayat (2) butir a, bahwa apabila anak akan bekerja harus terlebih dahulu memperoleh izin secara tertulis dari orang tua atau walinya, izin kerja terkait dengan hak dan kewajiban anak dan pengusaha, misalnya mengenai ketentuan jam kerja, pembayaran upah apakah sesuai dengan ketentuan yang berlaku, upah lembur, serta orang tua harus mengetahui apakah pekerjaan yang akan dilakukan anak tersebut tidak mengganggu perkembangan anak baik secara fisik, mental maupun sosialnya, dengan mengingat anak-anak masih memerlukan waktu dan kondisi yang memungkinkan anak dapat tumbuh kembang secara wajar.

Oleh karena itu, secara normatif dapat dikatakan, bahwa tidak adanya izin tertulis dari orang tua jelas menyalahi ketentuan Pasal 69 ayat (2) poin a Undang-undang No. 13 Tahun 2003 tentang Ketenagakerjaan dan hal ini merupakan pelanggaran persyaratan kerja dalam mempekerjakan anak yang dapat dikenakan sanksi sebagaimana yang diatur dalam ketentuan Pasal 185 UU Ketenagakerjaan, yang menentukan bahwa sanksi bagi pihak yang melanggar ketentuan Pasal 69 ayat (2) adalah pidana penjara paling singkat 1 tahun dan paling lama 4 tahun dan/atau denda paling sedikit Rp.100.000.000,- dan paling banyak Rp.400.000.000,-.

Kedua, tidak didasarkan pada perjanjian kerja.

Ketiga, kondisi jam kerja yang panjang. Hal ini tertuang dalam ketentuan Pasal 69 ayat (2) huruf c UU Ketenagakerjaan, yang mengatur bahwa pekerja anak maksimal bekerja selama 3 jam. Ketentuan tersebut sering dilanggar, meskipun sudah ada ketentuan pembatasan jam kerja bagi anak-anak yang bekerja, akan tetapi dalam kenyataannya anak-anak bekerja di atas 3 jam.

Keempat, Kondisi tempat kerja kurang kondusif dan terganggunya kesehatan pekerja anak. Pekerja anak di bawah umur, sering dihadapkan pada resiko-resiko pekerjaan yang dilakukannya, terutama yang bekerja di sektor industri, seperti resiko gangguan kesehatan akibat ruangan yang pengap, asap industri yang dapat menyesakan nafas, makan dan minum yang tidak terjamin dan kurang gizi, juga dihadapkan pada gangguan psikis seperti caci maki, kata-kata 
kasar, dan gangguan kehidupan sosialnya seperti hubungan dengan teman-teman sebaya.

Kelima, upah yang tidak sesuai ketentuan yang berlaku. Ketidak sesuaian upah yang dibayarkan kepada pekerja anak atau upah yang diperoleh oleh anak.

\section{Persamaan dan Perbedaan Perlindungan Hukum dalam Fiqh Jinâyah dan Undang-Undang no. 23 Tahun 2002.}

\section{Perbedaan}

Dari segi batasan umur, baligh menurut Islam usia minimal 12 (dua belas) tahun bagi laki-laki, dan minimal 9 (sembilan) tahun bagi perempuan. Pada usia inilah seseorang mengalami baligh dari segi usia. Apabila pada usia tersebut belum muncul tanda ihtilâm atau haid, maka fase baligh dari segi umur ditunggu sampai 15 (lima belas) tahun dan banyak perbedaan tentang umur anak yang belum dewasa. Sedangkan dalam Undang-undang no. 23 Tahun 2002 adalah dimana laki-laki maupun perempuan di atas 18 tahun maka baru di sebut dewasa dan dapat di pekerjakan.

Dari segi perlindungan hukum, dalam Islam menurut istilah ahli fiqh, melalui hadânah, berarti memelihara anak dari segala macam bahaya yang mungkin menimpanya, menjaga kesehatan jasmani dan rohaninya, menjaga makanan dan kebersihannya, mengusahakan pendidikannya sehingga ia sanggup berdiri sendiri dalam menghadapi kehidupan sebagai seorang muslim. Sedangkan dalam UU No. 23 Tahun 2002 pasal 59, menyebutkan bahwa "Pemerintah dan lembaga negara lainnya berkewajiban dan bertanggung jawab untuk memberikan perlindungan khusus kepada anak, dalam situasi darurat, anak yang berhadapan dengan hukum, anak dari kelompok minoritas dan terisolasi, anak yang tereksploitasi secara ekonomi dan/atau seksual, anak yang diperdagangkan, anak yang menjadi korban penyalahgunaan narkotika, alkohol, psikotropika dan zat adiktif lainnya (Napza), anak korban penculikan, penjualan dan perdagangan, anak korban kekerasan baik fisik dan/atau mental, anak yang menyandang cacat, dan anak korban perlakuan salah dan penelantaran.

Undang-undang membedakan antara kejahatan atau pelanggaran mengingat berat ringannya hukuman, sedangkan hukum Islam tidak membedakannya, semuanya disebut jarîmah mengingat sifat pidana nya. 
Suatu perbuatan dianggap jarîmah apabila dapat merugikan kepada aturan masyarakat, kepercayaan-kepercayaan, atau merugikan kehidupan anggota masyarakat, baik benda, nama baik atau perasaannya dengan pertimbangan-pertimbangan lain yang harus dihormati.

\section{Persamaan}

Dalam Islam memang tidak diatur secara langsung pekerja anak secara rinci, maka dari itu masuk dalam kategori jarîmah ta'zîr karena untuk menentukan ukuran atau batas hukumannya di pegang penuh oleh otoritas pemerintah dalam hal ini hakim dan otomatis di peraturanya menyesuaikan dengan pemerintah setempat dalam hal ini hukum di indonesia. Dan berikutnya adalah sama-sama melarang mempekerjakan anak di bawah umur ketika tidak sesuai dengan syaratsyarat yang di tentukan hukum seperti halnya ketika pekerjaan itu mengancam Hak-hak anak, sperti hak agar dapat hidup, berkembang dan mendapatkan pendidikan dan juga ketika terancam tereksploitasi ekonomi dan seksual. Dan jika para pengusaha atau seseorang melanggar ketentuan dalam hukum tersebut maka akan dikenai sanksi yang berlaku.

\section{Simpulan}

Perlindungan terhadap pekerja anak dalam hukum pidana Islam sudah diatur apabila pekerjaan itu banyak dan berat, maka anak kecil yang belum baligh tidak sah mengerjakannya. Kasus pekerja anak ini termasuk dalam jarîmah ta'zîr karena tidak diatur dalam Islam secara langsung dan wewenang sepenuhya dikembalikan kepada pemerintah. Semua perbuatan tersebut sangat dilarang oleh Islam karena dapat merusak tananan kehidupan berbangsa dan bernegara. Perlindungan hukum pekerja anak di sektor informal menurut Undang-undang No. 23 tahun 2002 tentang perlindungan anak, sudah diatur larangannya tentang pekerja anak tidak boleh tereksploitasi secara ekonomi harus dilindungi oleh pemerintah. Implementasi perlindungan khusus pemerintah mengeluarkan Undang-undang No. 13 tahun 2003 yang mengatur tentang syarat mempekerjakan anak yaitu anak bekerja di tempat kerja yaitu anak harus dipisahkan dari tempat kerja pekerja/buruh dewasa dan bagi pelaku yang mempekerjakan anak akan dikenai sanksi sesuai dengan ketentuan Undang-undang.

Dari segi persamaan hukum Islam dan Undang-undang, samasama melarang mempekerjakan anak di sektor informal, terutama jika 
syarat-syarat anak bekerja tidak terpenuhi maka itu melanggar hukum, dan perbedaannya anak bekerja hanya terletak pada batasan umur yang di dalam hukum pidana Islam bagi laki-laki 12 (dua belas) tahun, dan 9 (sembilan) tahun bagi perempuan. Maka fase baligh dari segi umur ditunggu sampai 15 (lima belas) tahun, sedangkan undang-undang adalah 18 tahun ke atas dan di dalam hukum pidana Islam tidak dijelaskan secara rinci tentang pekerja anak di sektor informal.

\section{Daftar Rujukan}

Abidin, Moch. Riza Zainal. Potret Anak di Jawa Tengah Yayasan Setar. Semarang: Puspa Swara, 2003.

Allen, Steven. Kata Sambutan Perwakilan UNICEF Indonesia dalam Undang-Undang No. 23 tahun 2002. Jakarta: Kementrian Pemberdayaan Perempuan Republik Indonesia \& Departemen Sosial republik Indonesia, 2002.

Attabik Ali, A. Zuhdi Muhdlor. Kamus Kontemporer Arab Indonesia. Jogjakarta: Multi Karya Grafika, 2003.

Azwar, Syaefuddin. Metode Penelitian Cet.IX. Yogyakarta: Pustaka Pelajar, 2009.

Cahyanto, Eka. Pedoman Teknis Pelayanan Pendidikan Bagi Pekerja Anak Sektor Informal. Jakarta: Depdiknas, 2001.

Departemen Agama RI. Al-Qur'an Tajwid dan Terjemahnya. Bandung: Diponegoro, 2008.

Dimyati (ad-), Abu Bakar bin as-Sayyid Muhammad Syata. I’ânah atTâlibîn. Semarang: Nur Asia, 1993.

Djazuli, A. Fiqh Siyasah. Bandung: Prenada Media, 2003.

Fachruddin, Fuad Mochamad. Masalah Anak dalam Hukum Islam Anak Kandung, Anak Tiri dan Anak Zina. Jakarta: Pedoman Jaya, 1985.

Ghufron, M. Pekerja Anak Bermasalah. Semarang: Puspa Swara, 2001.

Hanafi, Ahmad. Azaz-Azaz Hukum Pidana Islam. Jakarta: Bulan Bintang, 1976.

Jaziry (al-), Abdur Rahman. al-Fiqh 'Alâ Madhâhib al-'Arba'ah. Mesir: al-Maktabah al- Tijariah, t.th.

Jazuli, A. Fiqh jinayah Upaya Menanggulangi Kejahatan dalam Islam. Jakarta : PT. Raja Grafindo Persada, 2000. 
Kartasapoetra, G. Hukum Perburuhan di Indonesia Berlandaskan Pancasila. Jakarta: Sinar Grafika, 1994.

Khallaf, Abdul Wahab. Ilmu Ushul Fiqh. Semarang: Dina Utama Semarang, 1994.

Marsum. Jinayah Hukum Pidana Islam. Yogyakarta: FH UII,1991.

Munajat, Makrus. Hukum Pidana Islam di Indonesia. Yogyakarta: Teras, 2009.

Munawar (al-), Said Aqil. Hukum Islam \& Pluralitas Sosial. Jakarta: Paramadani, 2004.

Mushlih, Ahmad Wardi. Pengantar dan Asas Hukum Pidana Islam. Jakarta: Sinar Grafindo, 2004.

Mushlih, Ahmad Wardi. Pengantar dan Asas Hukum Pidana Islam. Jakarta: Sinar Grafindo, 2004.

Nashriana. Perlindungan Hukum Pidana Bagi Anak di Indonesia. Jakarta: Raja Grafindo Persada, 2011.

Sabiq, Sayyid. Fiqhus Sunnah. Bandung: al-Ma'arif, t.th.

Saparini, Hendri dan M. Chatib Basri. Pekerja Sektor Informal. Jakarta: FH UI, 1991.

Shiddiqi (as-), Hasbi. Pengantar Fiqh Mu'amalah. Jakarta: Bulan Bintang, 1989.

Suharsimi, Arikunto. Prosedur Penelitian Suatu Pendekatan Praktik. Jakarta: Rineka Cipta, 2010.

Syamsuddin. Petunjuk Pelaksanaan Penanganan Anak yang Bekerja. Jakarta: Departemen Tenaga Kerja Republik Indonesia, 1997.

Thalib, Sajuti. Hukum Kekeluargaan Indonesia. Jakarta: Penerbit Universitas Indonesia UI Press, 1986.

Ya’qub, Hamzah. Etos Kerja Islam. Jakarta: Pedoman Ilmu Jaya, 1992.

Ya'qub, Hamzah. Kode Etik Hukum Dagang Menurut Islam. Bandung: CV. Diponegoro, 1992.

Yahya, Mukhtar. Dasar-Dasar Pembinaan Hukum Islam. Bandung: alMa'arif, t.th.

Zulechaina Z, Muhammad Joni dan Tanamas. Aspek Hukum Perlindungan Anak dan Perspektif Konvensi Hak-hak Anak. Bandung: Citra Aditya Bakti, 1999. 
Undang-Undang Republik Indonesia No. 23 Tahun 2002 tentang Perlindungan Anak

Undang-Undang Republik Indonesia No. 13 tahun 2003 Tentang Tenaga Kerja

Hernawan, Ari. "Perlindungan Hukum bagi Pekerja Sektor Informal di Negara Berkembang", http://www.pkbh.ugm.ac.id/artkl.html, 18 November 2013

Nasihudin, Rofiq. "Pekerja Anak Bawah Umur Menurut Hukum Islam". http://www.nasihudin.com, 18 November 2013

Rosalin, Lenny N. "Kabupaten/Kota Layak Anak untuk Mewujudakan Indonesia Layak Anak", http://www.kotalayak anak.org, 23 Januari 2013

Sovalusian. "Analisis Studi Kasus Pekerja Anak”. 19 Oktober 2013

Sudaso, Cahyo. "Kasus Perbudakan di Pabrik Panci Tangerang". http://indiependen.com, 6 Februari 2014 